provides the opportunity to forge new alliances. Articles about information literacy are being written for professional journals and a series of videotapes related to information literacy are being produced. Efforts are currently underway in ACRL to work with the American Association for Higher Education on a program on the issue of information literacy.

Copies of the Final Report are available from the ALA office in Chicago. The ACRL Board has chosen information literacy as the theme for 1990-1991, and it will be the topic of my president's program at the ALA Annual Conference in 1991. Information literacy is an essential survival skill for the Information Age and libraries are an important part of the information universe. Preparing college and University populations to be efficient and effective information seekers and consumers is central to the mission of academic and research libraries. This is reflected in several places in the ACRL Strategic Plan including enhancing the capability of libraries to serve the needs of users and promoting study, research, and publication relevant to academic and research librarianship. It also builds on the themes of recent ACRL presidents and provides the opportunity to build upon past ACRL activities.

I would like to hear your ideas about how we, as an association, might continue to work on projects and programs relating to information literacy through efforts in ACRL and in academic and research libraries. This is an excellent opportunity to work with other units in ALA and other higher education groups and explore an important topic central to our functions as academic and research librarians.
Sources for information and ideas, in addition to the Final Report of the American Library Association Presidential Committee on Information Literacy include:

Patricia Senn Breivik, "Libraries Prepare for an Information Age," Educational Record 70 (Winter 1989): 13-19.

Patricia Senn Breivik. "Making the Most of Libraries Searching for Academic Excellence," Change 19 (July/August 1987): 44-52.

Patricia Semn Breivik and E. Gordon Gee, Information Literacy: Revolution in the Library. New York: American Council on Education, 1989.

Patricia Senn Breivik and Robert Wedgeworth, Libraries and the Search for Academic Excellence. Metuchen, N.J.: Scarecrow Press, 1988.

Larry Hardesty, Nicholas P. Lovrich, Jr., and James Mannon, "Library Use Instruction: Assessment of the Long-Term Effects," College \& Research Libraries 43 (January 1982): 38-46.

James A. Hyatt and Aurora A. Santiago, University Libraries in Transition. Washington, D.C.: National Association of College and University Business Officers, 1987.

Thomas Kirk, "Teaching and Technology: The Impact of Unlimited Information Access on Classroom Teaching," Library Issues: Briefings for Faculty and Administrators 9 (July 1989): $1-4$.

David W. Lewis, "Inventing the Electronic University," College b Research Libraries 49 (July 1988): 29I-304.

Barbara B. Moran. Academic Libraries: The changing Knowledge Center of Colleges and Universities. ASHE-ERIC Higher Education Research Report, No. 8. Washington, D.C.: Association for the Study of Higher Education, 1984.

\title{
ACRL Statement on the Certification and Licensing of Academic Librarians
}

At the 1989 ALA Annual Conference the ACRL Board of Directors approved the following statement:

"The Association of College and Research $\mathrm{Li}$ braries has affirmed that the master's degree from a program accredited by the American Library Association is the appropriate terminal professional degree for academic librarians. Therefore, it opposes certification or licensing in lieu of that degree for academic librarians, either by state agencies or by state or local professional associations."
The statement, prepared by ACRL's Academic Status Committee, does not oppose licensing or certification of librarians as an addition to an already obtained MLS, but only opposes it when it is substituted for eaming an MLS.

For further information, contact Mary Ellen Davis, ACRL Program Officer, ACRL/ALA, $50 \mathrm{E}$. Huron St., Chicago, IL 60611; (800) 545-2433.

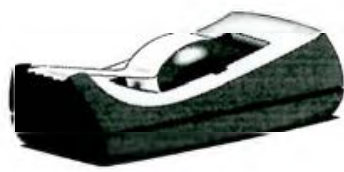

November 1989 / 893 